Wayan Sutarka, the Student of Faculty of Economics, Sriwijaya University, Palembang, Indonesia e-mail: wnsutarka@gmail.com

Isnurhadi, Ph.D. (Economics), Faculty of Economics, Sriwijaya University, Palembang, Indonesia e-mail: isnurhadi2020@gmail.com

Yuliani, Doctor of Economics, Faculty of Economics, Sriwijaya University, Palembang, Indonesia

ORCID ID: 0000-0003-3488-7941

e-mail: yulianisyapril@gmail.com

Agustina Hanafi, Doctor of Economics, Faculty of Economics, Sriwijaya University, Palembang, Indonesia e-mail: tinahanafi@ymail.com

\title{
The Determinants of Capital Structure of Listed Retailing Sector Companies on Indonesia Stock Exchange (IDX)
}

\begin{abstract}
Introduction. Capital structure must be the concern of the company's financial managers in expanding and financing the company's operations. The financing decisions that will be used must have strong implications for the value of the company in the future. The data used in this study were secondary data obtained from the Indonesia Stock Exchange website and from the HOTS PT application. Mirae Aset Sekuritas as well as from the official website of each company in the researched samples. The researched population was listed retailing sector companies on the Indonesia Stock Exchange (IDX) over the period of 2012-2016. The number of companies used was 18. The data analysis used panel data regression on the fixed effect assumption.

Purpose. The purpose of this study was to conduct an analysis and obtain empirical evidence of the effect of the Profitability, Tangibility, Firm Size, Growth Opportunity, Liquidity, Business Risk and Non-Debt Tax Shield variables on the capital structure.

Results. The results of the study showed that the capital structure (leverage) was influenced by variables of profitability, firm size, liquidity and non debt tax shields (NDTS). Variables of assets tangibility, growth opportunity and business risk did not affect the leverage.

Conclusion. The company finance managers should prioritize the internal funding sources and need to be thoroughly in utilizing external funding. The results of the analysis showed that the Pecking Order (POT) theory was more influential than the Trade-Off (TOT) theory. Internal financing sources were preferred to avoid high loan interest rates in Indonesia, foreign exchange risk losses for loans in foreign currencies, government regulations that limit the amount of interest costs that can be charged as tax deduction fees and the Indonesian economy which is vulnerable to global influences.

Keywords: Capital Structure; Profitability; Tangibility; Firm Size; Growth opportunity; Liquidity; Business risk; Non Debt Tax Shields.
\end{abstract}

Удк 339.9

Ваян Сутарка, студент факультету економіки, Університет Шривіджая, Палембанг, Індонезія Індонезія

Існурхаді, кандидат економічних наук, факультет Економіки, Університет Шривіджая, Палембанг,

Юліані, доктор економічних наук, факультет Економіки, Університет Шривіджая, Палембанг, Індонезія

Агустіна Ханафі, доктор економічних наук, факультет Економіки, Університет Шривіджая, Палембанг, Індонезія

\section{Детермінанти структури капіталу підприємств роздрібної торгівлі на фондовій біржі Індонезії}

Структура капіталу цікавить фінансових менеджерів компаній з позиції розширення і фінансуванні їх діяльності. Рішення про фінансування, які приймаються, мають важливі наслідки для зміни вартості компанії в

Стаття надійшла до редакції: 10.12 .2018

Received: 10 December 2018 
майбутньому. Дані, які використані в цьому дослідженні, були вторинними даними, отриманими з веб-сайту Індонезійській фондової біржі, програми HOTS PT. Mirae Aset Sekuritas, a також з офіційного сайту 18-ти досліджених компаній у пошуках зразків за період 2012-2016 рр. При аналізі даних використовувалася панель регресії даних в припущенні про фіксований ефект. Мета цього дослідження полягала в аналізі і отриманні емпіричних доказів впливу змінних величин прибутковості, матеріальної цінності, розміру фірми, можливості зростання, ліквідності і підприємницького ризику на структуру капіталу. Результати дослідження показали, що на структуру капіталу впливали змінні прибутковості, розміру фірм, ліквідності. Змінні матеріальних активів, можливості зростання і бізнес-ризики не впливали на левередж. Доведено, що фінансові менеджери компанії повинні визначити пріоритети внутрішніх джерел фінансування і ретельно використовувати зовнішнє фінансування. Результати аналізу показали, що теорія Pecking Order була більш впливовою, ніж теорія компромісу.

Ключові слова: структура капіталу; рентабельність; бізнес-ризик; ліквідність.

Problem statement. The hypothesis publication of Modigliani and Miller (1958) was considered as a research milestone in capital structure and its effect on company value. After that, many researches have been conducted to determine the effect of determinants of capital structure on the selection of capital structures and their effect on company value. Some theories that have become references in further research include Jensen and Meckling (1976) known as "theory of agency cost", Breadley et al. (1984) was known as "static trade-off theory", and Myers and Majhluf (1984) suggested"pecking order theory" (Quan, 2002). Trade-off theory (TOT) and pecking order theory were the two most prominent theories.

The retailing sector is one of the fastest growing sectors in Indonesia. Factors driving the growth of the retail sector are Indonesia's demographic structure dominated by young people who will increase the number of productive workforce with disposible income and increasing needs, changes in lifestyle and consumption patterns of the Indonesian people, the number of middleincome people who continue growing, the incessant campaign of non-cash transactions and the development of entertainment combined with primary needs.

The developing companies need large funds. There are two funding sources, internal and external. Internal funding sources come from company profits and from external sources of debt and the issuance of new shares. Managers must choose the best funding source to avoid financial distress.

Researches conducted in several countries showed inconsistent effects of several variables on capital structure. Variables that still show inconsistent results include: profitability, assurance, firmsize, growth opportunity, liquidity, business risk and non debt tax shield.

Test Results. The research samples were selected by purposive sampling method because the retailing sector of companies did not always submit annual reports. The criteria for selecting samples were as follows (table 1).

Table 1 Population Criteria

\begin{tabular}{|c|c|c|}
\hline No & \multicolumn{1}{|c|}{ Criteria } & Total Company \\
\hline 1. & Total retailing sector companies & 25 \\
\hline 2. & Expelled due tounregistered in 2012 & $(5)$ \\
\hline 3. & $\begin{array}{l}\text { Expelled due to no financial statements } \\
\text { over the period of 2012-2016 }\end{array}$ & $(2)$ \\
\hline & Total samples & 18 \\
\hline
\end{tabular}

Source: The number of retail: companies in Indonesia during 2012-2016

The list of companies met the criteria as follows (table 2).

Table 2 List of Research Sample Companies

\begin{tabular}{|c|l|c|}
\hline No & \multicolumn{1}{|c|}{ Emiten } & Code \\
\hline 1. & PT Ace Hardware Indonesia Tbk. & ACES \\
\hline 2. & PT Sumber Alfaria Trijaya Tbk. & AMRT \\
\hline 3. & $\begin{array}{l}\text { PT Centratama Telekomunikasi Indonesia } \\
\text { Tbk. }\end{array}$ & CENT \\
\hline 4. & PT Catur Sentosa Adiprana Tbk. & CSAP \\
\hline 5. & PT Electronic City Indonesia Tbk. & ECII \\
\hline 6. & PT Erajaya Swasembada Tbk. & ERAA \\
\hline 7. & PT Global Teleshop Tbk. & GLOB \\
\hline 8. & PT Visi Telekomunikasi Infrastruktur Tbk. & GOLD \\
\hline 9. & PT Hero Supermarket Tbk. & HERO \\
\hline
\end{tabular}

\begin{tabular}{|c|l|c|}
\hline No & \multicolumn{1}{|c|}{ Emiten } & Code \\
\hline 10. & PT Kokoh Inti Arebama Tbk. & KOIN \\
\hline 11. & PT Matahari Department Store Tbk. & LPPF \\
\hline 12. & PT Mitra Adiperkasa Tbk. & MAPI \\
\hline 13. & PT Midi Utama Indonesia Tbk. & MIDI \\
\hline 14. & PT Matahari Putra Prima Tbk. & MPPA \\
\hline 15. & PT Ramayana Lestari Sentosa Tbk. & RALS \\
\hline 16. & PT Supra Boga Lestari Tbk. & RANC \\
\hline 17. & PT Sona Topas Tourism Industry Tbk. & SONA \\
\hline 18. & PT Tiphone Mobile Indonesia Tbk. & TELE \\
\hline
\end{tabular}

Source: List of sample retail companies 
The number of companies met the criteria were 18 companies with an observation period $(t)=5$ years $(2012-$ 2016) and the number of companies $(n)=18$ so that the total number of observational data becomes 90 units of data. From those units of data, 1 (one) unit was expelled, data from PT Sona Topas Tourism Industry Tbk in 2016, because the value of the business risk variable $\left(X_{6}\right)$ was too large, so the data observed becomes 89 unit of data.

This study used panel data regression with the following equation (1).

$\mathrm{Y}=b_{0}+b_{1} \mathrm{X}_{1}+b_{2} \mathrm{X}_{2}+b_{3} \mathrm{X}_{3}+b_{4} \mathrm{X}_{4}+b_{5} \mathrm{X}_{5}+b_{6} \mathrm{X}_{6}+b_{7} \mathrm{X}_{7}+e$
The variables used in this study were independent variables and dependent variables. Independent variable is a variable considerd to affect other variables. The independent variables in this study were profitability, assurance, firm size, growth opportunity, likquidity, business risk and non debt tax shield. Dependent variable was capital structure (leverage).

Descriptive statistics aimed to provide an overview or description of the data collected in the study. The results of the disk statistics are as follows (table 4).

Table 4 Descriptive Statistics of Research Variables

\begin{tabular}{|l|c|c|c|c|c|}
\hline \multicolumn{1}{|c|}{ Variables } & $\mathrm{N}$ & Min & Max & Mean & Std. Deviation \\
\hline Leverage & 89 & 0.020 & 10.120 & 0.619 & 1.056 \\
\hline Profitability & 89 & -1.580 & 0.460 & 0.054 & 0.201 \\
\hline Tangibility & 89 & 0.010 & 0.900 & 0.243 & 0.184 \\
\hline FirmSize & 89 & 25.040 & 30.600 & 28.429 & 1.297 \\
\hline Growth & 89 & -0.960 & 6.750 & 0.281 & 0.813 \\
\hline Liquidity & 89 & 0.110 & 14.030 & 2.497 & 2.457 \\
\hline Business risk & 89 & 1.350 & 1.920 & 0.082 & 0.456 \\
\hline NDTS & 89 & 0.010 & 1.040 & 0.168 & 0.163 \\
\hline
\end{tabular}

Source: modified Output Eviews 9

Panel fund regression have 3 (three) models, namely Common Effect (CE) or Pooled Least Square (PLS), Fixed Effect (FE) and Random Effect (RE). The common effect model (CE) is the simplest panel data regression approach, only integrates time series data and cross section data without regard to time dimensions and individual entities or it is assumed that the behavior of company data is the same in various time periods. The Ordinary Least Square (OLS) approach is commonly used in the CE model.

The fixed effect model (FE) is a panel data regression model considering the differences among individuals can be accommodated from the difference in its intercepts. The fixed effect model uses dummy variables to capture intercept differences between individuals so that it is often called the least square dummy variable (LSDV). The difference in interception is caused by managerial, intensive and work culture.

The third panel data regression model is the random effect (RE) model. It carries out panel data estimation assuming that interfering variables may be interconnected between time and between individuals. In this model the difference in intercepts is accommodated by the error terms of each company.

To determine the best model whether it is common effect, fixed effect or random effect, a Chow Test was performed (choosing between the best CE and FE models), Hausman Test (choosing the best model between FE and $\mathrm{RE}$ ) and Langragge Multiplier Test (choosing the best model between (CE and re). The Chow Test results are as follows (table 5).

Table 5 F (Chow Test) Test Results

\begin{tabular}{|c|c|}
\hline Cross-section $\mathrm{F}$ & P-value(Probability) \\
\hline 37,327246 & 0,0000 \\
\hline
\end{tabular}

Source: Modified Output Eviews 9

Based on the table above, the value of $\mathrm{P}$-value The results of the Hausman Test are as follows (table 6). (Probability) $<0.05$, it concluded that the FE model was better than the CE model.

Table 6. Results of the Hausman Test

\begin{tabular}{|c|c|}
\hline Chi-Sq. Statistic & P-value(Probability) \\
\hline 30,300220 & 0,0001 \\
\hline
\end{tabular}

Source: Modified Output Eviews 9 
The Hausman test results obtained a Probability value of $0,0001<0,05$, it concluded that the fixed effect model (FE) was better than random effect (RE).

Based on the results of the Chow Test and Hausman Test, it concluded that the best model was FE, so no need to conduct Langragge Multiplier Test. The classic assumption test was conducted to obtain regression equation BLUE (Best Linear Unbiased Estimators).Normality Test with the Lilliefors Method (table 7).

Table 7 Results of Testing the Lilliefors Method

\begin{tabular}{|c|c|}
\hline DLilliefors statistics & P-value(Probability) \\
\hline 0.083146 & 0,1 \\
\hline
\end{tabular}

Source: Modified Output Eviews 9

The P-value (Probability)> 0.05, it can be concluded that the research data was normally distributed.
The symptoms of autocorrelation in Eviews 9 tested by looking at the AC-PAC plot. The results were as follows (fig. 1).

Date: 11/27/18 Time 21:51

Sample: 20122016

Includes observations: 89

\begin{tabular}{|c|c|c|c|c|c|}
\hline $\begin{array}{c}\text { Auto } \\
\text { correlation }\end{array}$ & $\begin{array}{c}\text { Partial } \\
\text { Correlation }\end{array}$ & $A c$ & PAC & Q-Stat & Prob \\
\hline & & 10.058 & 0.058 & 0.3075 & 0.579 \\
\hline 1 & $1 \longdiv { 1 }$ & $2-0.125$ & -0.129 & 1.7574 & 0.415 \\
\hline ' & 1 & $3-0.261$ & -0.251 & 8.1819 & 0.042 \\
\hline $1 \square$ & 1 & $4-0.172$ & -1.177 & 10.995 & 0.027 \\
\hline
\end{tabular}

Source: processed data

The results of the ACF and PACF plots showed that no margin appeared except the lag-3, so this condition can be concluded that the residual model was not autocorrelated

because most ACF-PACF plots were within the error margin line.

Heteroscedasticity test. Tests were carried out with the White Test as follows (table 8).

Table 8 White Test Results

\begin{tabular}{|l|c|c|c|c|}
\hline \multirow{2}{*}{$\begin{array}{l}\text { Predictor } \\
\text { Variables }\end{array}$} & \multicolumn{2}{|c|}{ t-test } & \multicolumn{2}{c|}{ F-test(ANOVA) } \\
\cline { 2 - 3 } & Beta coefficient & P-value (Sig) & F statistics & P-value (Sig) \\
\hline Constants & 0.128557 & 0.2636 & 0.707049 & 0.666037 \\
\hline Profitability & 0.005270 & 0.8386 & & \\
\hline Tangibility & 0.022053 & 0.4233 & & \\
\hline Firm Size & -0.004061 & 0.3063 & & \\
\hline Growth & -0.003727 & 0.5373 & & \\
\hline Liquidity & 0.001954 & 0.3157 & & \\
\hline Business risk & 0.004201 & 0.6951 & & \\
\hline NDTS & 0.014649 & 0.6580 & & \\
\hline
\end{tabular}

Source: Modified Output Eviews 9

From the output results in the t-test, all P-values (Sig.) were obtained greater than $5 \%$ (not significant). On the other hand in the F-test, it was also obtained that the Pvalue (Sig.) was greater than $5 \%$ (not significant). Thus, the results of this test concluded that the Residual model was not Heteroscedaticity.
Multicollinearity Test. For Multicollinearity assumptions, VIF values were tested from the estimation results of the regression model predictor $X_{1}$ to $X_{7}$ on the response variable of $Y$ (table 9).

Table 9 Mulikolinieritas Test Results

\begin{tabular}{|c|c|c|c|c|}
\hline Variables & CoefficientVariance & UncenterdVIF & Centered VIF & Conclusion \\
\hline Profitability & 4.079106 & 10279.86 & NA & Multicollinearity was not present \\
\hline Tangibility & 0.030767 & 2.254297 & 2.026879 & Multicollinearity was not present \\
\hline Firm Size & 0.187755 & 29.31538 & 1.419261 & Multicollinearity was not present \\
\hline
\end{tabular}


Електронне наукове фахове видання з економічних наук "Modern Economics», №12 (2018), 26-33 https://modecon.mnau.edu.ua | ISSN 2521-6392

\begin{tabular}{|c|c|c|c|c|}
\hline \multicolumn{5}{|c|}{ Continuation } \\
\hline Growth & 0.004836 & 9852.868 & 2.568595 & Multicollinearity was not present \\
\hline Liquidity & 0.000875 & 1.350066 & 1.175633 & Multicollinearity was not present \\
\hline Business risk & 0.000255 & 5.208286 & 1.198239 & Multicollinearity was not present \\
\hline NDTS & 0.002694 & 1.437205 & 1.392033 & Multicollinearity was not present \\
\hline
\end{tabular}

Source: processed Secondary Data

Table 9 above shows that all independent variables had VIF values $<10$ so that there were no symptoms of multicolineirity.

From the results of the classical assumption of the regression model test, it was concluded that the model had passed the classic assumption problem. Furthermore, the panel data regression model was estimated on the fixed effect assumption. The results of testing with the EViews 9 program are as follows (table 10).

Table 10 Regression Output of Data Panel Fixed Effect

\begin{tabular}{|c|c|c|c|c|}
\hline \multicolumn{5}{|c|}{ Total panel (unbalanced) observations: 89} \\
\hline Variable & Coefficient & Std. Error & t-Statistic & Prob. \\
\hline $\mathrm{C}$ & 11.84955 & 2.019680 & 5.867044 & 0.0000 \\
\hline $\mathrm{X}_{1}$ & -5.221720 & 0.175406 & -29.76931 & 0.0000 \\
\hline$x_{2}$ & -0.004107 & 0.433307 & -0.009478 & 0.9925 \\
\hline$x_{3}$ & -0.374651 & 0.069543 & -5.387309 & 0.0000 \\
\hline $\mathrm{X}_{4}$ & 0.002969 & 0.029582 & 0.100362 & 0.9204 \\
\hline$X_{5}$ & -0.069762 & 0.015977 & -4.366459 & 0.0000 \\
\hline$X_{6}$ & 0.062289 & 0.051901 & 1.200149 & 0.2345 \\
\hline $\mathrm{x}_{7}$ & -0.761305 & 0.308010 & -2.471687 & 0.0161 \\
\hline \multicolumn{5}{|c|}{ Effects Specification } \\
\hline \multicolumn{5}{|c|}{ Cross-section fixed (dummy variables) } \\
\hline \multicolumn{2}{|c|}{ R-squared } & 0.976983 & Mean dependent var & 0.618652 \\
\hline \multicolumn{2}{|c|}{ Adjusted R-squared } & 0.968351 & S.D. dependent var & 1.056339 \\
\hline \multicolumn{2}{|c|}{ S.E. of regression } & 0.187925 & Akaike info criterion & -0.273506 \\
\hline \multicolumn{2}{|c|}{ Sum squared resid } & 2.260204 & Schwarz criterion & 0.425549 \\
\hline \multicolumn{2}{|c|}{ Log likelihood } & 37.17104 & Hannan-Quinn criter. & 0.008263 \\
\hline \multicolumn{2}{|c|}{ F-statistic } & 113.1872 & Durbin-Watson stat & 1.598353 \\
\hline \multicolumn{2}{|c|}{ Prob(F-statistic) } & 0.000000 & & \\
\hline
\end{tabular}

1. Simultaneous Testing on Effect Hypothesis.

To test the simultaneous effect of independent variables on the dependent variable, F. Test was conducted. Significant effects simultaneously when Pvalue $\leq \alpha$ with $\alpha$ determined at $5 \%$.

Based on the output results obtained F-statistic value of 133.1872 with Prob (F-statistic) of $0.000000<5 \%$ ) so it can be concluded that variables $\mathrm{X}_{1}, \mathrm{X}_{2}, \mathrm{X}_{3}, \mathrm{X}_{4}, \mathrm{X}_{5}, \mathrm{X}_{6}$, and $\mathrm{X}_{7}$ simultaneously had a significant effect on $Y$. Simultaneously these variables were able to explain $97.70 \%$ diversity of leverage variables and the remaining $2.30 \%$ explained by error variables or other variables not included in the model.

2. Partial / Individual Testing on the effect Hypothesis.

Testing the effect of partial / individual independent variables was done through testing the partial coefficient of the Test model where the conclusion of significant effect of a variable was obtained if the $P$-value $\leq \alpha$ with $\alpha$ determined at $5 \%$.

$\mathrm{H}_{1}$ : Profitability variable had a significant effect on capital structure.
The effect of $X_{1}$ on $Y$ with a regression coefficient (coefficient) of -5.221720 (negative influence) and P-value (Prob.) of 0.0000 so it can be concluded that there was a significant effect of $X_{1}$ on $Y$ which was -5.100254 . In other words, if profitability increases by 1 unit, then leverage will decrease by 5,100254 units, and vice versa if profitability decreases by 1 unit, then leverage will increase by 5,100254 units. Therefore, $\mathrm{H}_{1}$ was accepted and it can be concluded that the profitability variable had a significant effect on the capital structure. The results of this analysis were in accordance with the pecking order theory.

$\mathrm{H}_{2}$ : Assettangibility variable had a significant effect on capital structure.

The test result of the effect of variable $X_{2}$ partially on $Y$ produced a regression coefficient of -0.004107 and $P$ value (Prob.) of 0.9925 greater than 0.05 (0.9925> 0.05), so it can be concluded that there was no significant partial effect of variable $X_{2}$ on variable $Y$. The results of the test contradicted with the pecking order theory (POT) and trade-off theory (TOT), both predicted that positive effects caused by large assets available as collateral. 
Bank lending rates are quite high in Indonesia make retailing sector companies listed on the IDX avoid expanding and investing with financing from bank loans. High interest rates cause interest costs to be very large which can increase the company's financial risk. Besides high interest rates, the Indonesian economy is also vulnerable to world economic turmoil such as the volatility of the Rupiah exchange rate against foreign currencies. If a company decides to take loans from foreign banks in foreign currencies, it may be possible to obtain lower loan interest rates but face the risk of a decrease in the exchange rate which will cause a loss in foreign exchange differences.

To get tax benefits from charging interest fees in Indonesia today, it is no longer effective. Because the current tax regulations in Indonesia only allow to charge interest only for interest costs up to loan value of 4 (four) times the company's net capital. If the amount of the loan exceeds this provision, then the interest expense incurred cannot be charged as a deduction for corporate income tax.

From above description, the researcher concluded that the tangibility variable did not affect leverage because of high domestic loan interest rates, the risk of foreign exchange loss for foreign loans, and the existence of rules on limiting interest costs as deduction from income tax.

$\mathrm{H}_{3}$ : Firmsize variables had a significant effect on capital structure.

Variable $\mathrm{X}_{3} \mathrm{On} \mathrm{Y}$ with a regression coefficient (coefficient) of -0.374651 and P-value (Prob.) of 0.0000 $<0.05$, so the test results showed that there was a significant effect of $X_{3}$ on $Y$ of $-0,374651$. The results of testing the significant effect of firmsize variables on retailing sector companies supported the pecking order theory where significant negative effects were caused by large companies experiencing asymmetric information problems and large companies did not need to send sensitive signals to investors besides the resulting profits were quite large (Al-Ajmi et al., 2009).

$\mathrm{H}_{4}$ : Growth opportunity variable had a significant effect on capital structure.

Partially, the effect of variable $\mathrm{X}_{4}$ on $\mathrm{Y}$ based on the test results obtained regression coefficient (coefficient) of 0.002969 and a P-value (Prob.) of 0.9204>0.05. The value of P-value (Prob.) showed that there was no partial significant from variable $\mathrm{X}_{4}$ to variable $\mathrm{Y}$. The results were not significantly contradictory to theory, both the POT theory (Karadeniz et al. 2009; Chen et al. 2014) and the TOT theory (Gomez et al. 2014; Vo 2016).

The growth of the retailing sector company is not used for the convenience of obtaining credit because the concerns of company managers will decrease people's purchasing power. Consumers of retailing companies generally are people who consume goods and services. The purchasing power of the Indonesian people is very much influenced by the prices of several commodities such as the prices of agricultural and plantation products and will decline only by the issue of rising fuel prices. Community consumption usually increases in certain seasons such as religious holidays. Demand is unstable throughout the year so it is risky for companies to pay debt at a rateinterest in Indonesia is quite high every month. The manager's concern with the decrease in consumer purchasing power causes growth opportunities does not increase debt (no positive effect on leverage).

$\mathrm{H}_{5}$ : Liquidity Variabel had a significant effect on capital structure.

Testing the effect of variable $X_{5}$ on $Y$ obtained regression coefficient (Coefficient) of -0.069762 and $P$ value (Prob.) of $0.0000<0.05$. These results show that there is a significant negative effect of $X_{5}$ on $Y$ at 0.069762 . This result is in accordance with the pecking order theory which states that high liquidity indicates positive working capital and the existing sources of funds are safe to finance long-term investments so there is no need for funding sources external (Myers and Majhluf, 1984; Haron, 2016).

$\mathrm{H}_{6}$ : Business risk variable had a significant effect on capital structure.

The test result fom effect of $X_{6}$ variables partially on $Y$ obtained a regression coefficient (Coefficient) of 0.062289 and P-value (Prob.) of $0.2345>0.05$, so it can be concluded that there was no significant partial effect of variable $X_{6}$ on variable $Y$. The results of this test did not support either the POT or TOT theory which both predicted that the results of negative influences. The test results supporting the results of previous studies conducted among other researchers (Tippayana, 2014, Hamida, 2014 and Gómez et al., 2014).

According to Abdillah et al. (2017) that the bussiness risk variable did not affect on go public companies in Indonesia because managers in making funding decisions pay less attention to business risk issues because they pay more attention to macroeconomic factors. Indonesia's macroeconomic conditions continue to be revised during the study period. Because managers had been able to measure the level of risk to be faced, these variables were not a concern in funding decisions.

$H_{7}$ : The NDTS variable had a significant effect on the capital structure.

The effect of Partial $X_{7}$ Variable on $Y$ resulted in $a$ regression coefficient of -0.761305 and $P$-value (Prob.) of $0.0161<0.05$, so the results of the test can be concluded that there was a significant partial effect of the $X_{7}$ variable on $Y$. The significant effect due to the companies were afraid of facing the risk of default because the addition of debt, so that they used depreciation and amortization to obtain greater tax benefits. This result was in accordance with the theory of pecking order and trade off theory.

Conclusion. The determinants of the capital structure of this study were determined by profitability variables, firm size, liquidity and non debt tax shields (NDTS), it had a significant negative effect on capital structure. 
Tangibility variables, growth opportunity and business risk did not significantly influence the capital structure. In general, funding decisions on retailing sector companies listed on the Indonesia Stock Exchange (IDX) were more influenced by the pecking order theory.

The analysis showed that the structure of the retailing sector company model in Indonesia was more affected by the pecking order theory. Therefore, managers before making funding decisions are expected to prioritize internal funding before using external funding to avoid financial distress. Interest on bank loans in Indonesia is quite high, so a manager must be careful in expanding and funding sources.

The data used in this study were limited to quantitative data sourced from the company's financial statements. It is expected for future researcher will include other variables out of the financial statements such as macroeconomic variables.

\section{References:}

1. Abdillah, A. N., Ikhsan, S. \&Mutia, I. (2017). Factors Affecting Structure of Go PublicManufacturing Companies in BEI (Indonesia Stock Exchange). International Journal of Accounting Research, 6(1), 173. DOI: 10.4172/2472-114X.1000173.

2. Abdulla, Y. (2017). Capital structure in a tax-free economy: evidence from UAE. International. Journal of Islamic and Middle Eastern Finance and Management, 10, 1, 102-116. DOI: 10.1108/IMEFM-11-2015-0144.

3. Al-Ajmi, J., Hussain, H. A. \& Al-Saleh, N. (2009). Decisions on Capital Structure ina Zakat Environment with prohibition of Riba. Journal of Risk Finance, 10, no.5, 460-476. DOI: https://doi.org/10.1108/15265940911001376

4. Alipour, M., Mohammadi, M.F.S \& Derakhshan, H. (2015). Determinants of capital structure: an empirical study of firms in Iran. International Journal of Law and Management, 57, 1, 53-83. DOI: http://dx.doi.org/10.1108/IJLMA-01-2013-0004.

5. Al-Najjar, B. \&Khaled Hussainey, (2011). Revisiting The Capital-Structure Puzzle: UK Evidence. The Journal of Risk Finance, 12, 4, 329-338. DOI: https://doi.org/10.1108/15265941111158505.

6. Al-Najjar, B. \& Taylor, P. (2008). The relationship between capital structure and ownership structure new evidence from Jordanian panel data. Managerial Finance, 34, 12, 919-933. DOI: https://doi.org/10.1108/03074350810915851.

7. Amidu, M. (2007). Determinants of CapitalStructure of Banks in Ghana: An Empirical Approach. Baltic Journal of Management, 2, 1, 67-79. DOI: https://doi.org/10.1108/17465260710720255.

8. Arifin, J. (2014). SPSS 24 Untuk Penelitian dan Skripsi (Cetakan Pertama). PT Elex Media Komputindo, Jakarta, Indonesia.

9. Ardalan, K. (2007). Capital Structure Theory: Reconsidered. Research in International Business and Finance, 39, 3, 696-710.

10. Audriene, D. (2016). Sukses di Singapura dan Malaysia, Erajaya Bidik Negara Ketiga. Retrieved from https://www.cnnindonesia.com/ekonomi/20160609150544-92-136954/.

11. Bandyopadhyay, A. \& Barua, N. M. (2016). Factors Determining Capital Structure and Corporate Performance in India: Studying the Business Cycle Effects. The Quarterly Review of Economics and Finance, 61(C), 160-172. DOI: https://doi.org/10.1016/j.qref.2016.01.004.

12. Baskoro, F. M. (2017). Indonesia Masuk Lima Besar Sektor Ritel Paling Potensial di Dunia. Retrieved from http://www.beritasatu.com/ekonomi/368786/.

13. Basuki, A. T. \& Nano, P. (2016). Analisis Regresi Dalam Peneletian Ekonomi dan Bisnis (Dilengkapi Aplikasi SPSS \& Eviews). Divisi Buku Perguruan Tinggi PT Rajagrafindo Persada, Jakarta, Indonesia.

14. Bradley, M., Jarrell, G. A. \& Kim, E. (1984). On the existence of optimal capital structure: Theory \& Evidence. Journal of Finance, 39(3), 857-878. DOI: https://doi.org/10.1111/j.1540-6261.1984.tb03680.x.

15. Chadha, S. \& Sharma, A. K. (2015). Determinants of Capital Structure: An Empirical Evaluation from India. Journal of Advances inManagement Research, 12(1), 3-14. DOI: https://doi.org/10.1108/JAMR-08-2014-0051.

16. Chen, J, C. Jiang dan Y. Lin (2014). What determine firms' capital structure in China. Managerial Finance, 40, 10, $1024-1039$. DOI: https://doi.org/10.1108/MF-06-2013-0163.

17. Dao, M. Q. (2017). Determinants of The Global Financial Crisis Recovery: An Empirical Assessment. Journal of Economic Studies, 44(1), 36-46. DOI: https://doi.org/10.1108/JES-09-2015-0160.

18. Data Base (2017). Riset Tren Pertumbuhan Minimarket, Supermarket, Hypermarket 2015-2018. Retrieved from http://www.Industri.com/.

19. Dawar, V. (2014). Agency Theory, Capital Structure and Firm Performance: Some Indian Evidence. Managerial Finance, 40(12), 1190-1206. DOI: https://doi.org/10.1108/MF-10-2013-0275.

20. Dugan, M. T., Medcalfe, S. K. \& Park, S. H. (2018). A Reconsideration of perating- Financial Leverage Tradeoff Hypothesis. Journal of Financial Economic Policy, 10(4), 473-483. DOI: https://doi.org/10.1108/JFEP-01-2018-0005.

21. Fahmi, I. (2014). Manajemen Keuangan Perusahaan dan Pasar Modal, Mitra Wacana Media, Jakarta, Indonesia.

22. Ferdinand, A. (2017). Metode Penelitian Manajemen (Edisi Kelima), Badan Penerbit Universitas Diponogoro, Semarang, Indonesia.

23. Florentina, I. E. (2010). Interdependensi Antara Insider Ownership, Keputusan Investasi dan Risiko Bisnis. Jurnal Keuangandan Perbankan, 17(1), 50-60.

24. Glover, K. J. \& Hambusch, G. (2014). The Trade-Off Theory Revisited: On The Effect Of Operating Leverage. International Journal of Managerial Finance, 10(1), 2-22.

25. Gomez, G., Rivas, A. M. \& Bolanos, E.R.L. (2014). The Determinants of CapitalStructure in Peru. Academia Revista Latino Americana de Administración, 27(3), 341-354. DOI: https://doi.org/10.1108/ARLA-01-2014-0007.

26. Hakim, A. (2014). Pengantar Ekonometrika dengan Aplikasi Eviews (Cetakan Pertama), Ekonisia, Yogyakarta, Indonesia.

27. Hamidah (2014). Analysis Of Factors Affecting The Capital Structure And Profitability in Indonesian'S Manufacturing Company Year 2009 - 2013. Tesis Universitas Negeri Jakarta, Jurnal Keuangan dan Perbankan, 20(2), pp.157-165. 
28. Haron, R. (2016). Do Indonesian firms practice target capital structure a dynamic approach. Journal of Asia Business Studies, 10(3), 318-334. DOI: https://doi.org/10.1108/JABS-07-2015-0100.

29. Husnan, S., Dan, E. \& Pudjiastuti (2015). Dasar-Dasar Manajemen Keuangan (Edisi Ketujuh). Yogyakarta: UPP STIM YKPN.

30. Irianto, A. (2015). Statistik Konsep Dasar, Aplikasi, dan Pengembangannya (Edisi Keempat). Jakarta: Prenadamedia Group.

31. Jager, P. (2008). Panel data techniques and accounting research. Meditari Accountancy Research, 16(2), 53-68. DOI: https://doi.org/10.1108/10222529200800012.

32. Karadeniz, E. S.Y. Kandir, M. B. \& Onal, Y. B. (2009). Determinants of capital structure: evidence from Turkish lodging companies. International Journal of Contemporary Hospitality Management, 21(5), 594-609. DOI: https://doi.org/10.1108/09596110910967827.

33. Kellermann, K. \& Schlag, C. (2013). Occupy risk weighting: howthe minimum leverage ratiodominates capital requirements A Swiss example. Journal of Financial Regulation andCompliance, 21(4), 353-372.

34. Komara A. S. Hartoyo dan T. Andati (2014). Analisis Pengaruh Struktur Modal Terhadap Kinerja Keuangan Perusahaan. Jurnal KeuangandanPerbankan, 20(1), 10-21.

35. Kumar, S. (2017). Research On Capital Structure Determinants: A Review And Future Directions. International Journal of Managerial Finance, 13(2), 106-132. DOI: https://doi.org/10.1108/IJMF-09-2014-0135.

36. Li, H. \& Stathis, P. (2017). Determinants Of Capital Structure In Australia: An Analysisof Important Factors. Managerial Finance, 43(8), 881-897. DOI: https://doi.org/10.1108/MF-02-2017-0030.

37. Liang, J., Li, L. F. \& Song, H. (2007). An Explanation of Capital Structure of China's Listed Property Firms. Property Management, 32(1), 4-15. DOI: https://doi.org/10.1108/PM-02-2013-0012.

38. Morri, G. \& Beretta, C. (2008). The capital structure determinants of REITs. Is it a peculiar industry. Journal of European Real Estate Research, 1(1), 6-57. DOI: https://doi.org/10.1108/17539260810891488.

39. Myers, S. C. (1984). The capital structure puzzle. Journal of Finance, 39(3), 57-92. DOI: https://doi.org/10.2307/2327916.

40. Myers, S. C. \& Majluf, N. S. (1984). Corporate financing and investment decisions when firm shave information that investors do not have. Journal of Financial Economics, 13(2), 187-221. DOI: https://doi.org/10.1016/0304-405X(84)90023-0.

41. Peraturan Presiden Republik Indonesia Nomor 112, Tahun 2007 Tentang Penataan Dan Pembinaan Pasar Tradisional, Pusat Perbelanjaan Dan Toko Modern.

42. Pohan, A. Alfamart semakin eksis di Filipina. Retrieved from https://industri.kontan.co.id/news/.

43. Pramesti, G. (2016). Statistik Lengkap Secara Teori dan Aplikasi dengan SPSS 23. Jakarta: Kompas Gramedia.

44. Priyatno, D. (2017). Panduan Praktis Olah Data Menggunakan SPSS. Yogyakarta: Penerbit Andi (Anggota IKAPI).

45. Quan, V.D.H. (2002). A Rational Justification of The Pecking Order Hypothesis to The Choice of Sources of Financing. Management Research News, 25(12), 74-90. DOI: https://doi.org/10.1108/01409170210783296.

46. Ramjee, A. \& Gwatidzo, T. (2012). Dynamics in capital structure determinants in South Africa Meditari. Accountancy Research, 20(1), 52-67.

47. Su, K. R. \& Landan, B. (2013). Ultimate ownership, institutionality, and capital structure: Empirical analyses of Chinese data Chinese. Management Studies, 7(4), 557-571.

48. Thippayana, P. (2014). Determinants of Capital Structure in Thailand. Procedia - Social and Behavioral Sciences. 143, 10741077. DOI: https://doi.org/10.1016/j.sbspro.2014.07.558.

49. Vasiliou, D., Eriotis, N. \& Daskalakis, N. (2009). Testing the pecking order theory: the importance of methodology. Qualitative Research in Financial Markets, 1(2), 85-96. DOI: https://doi.org/10.1108/17554170910975900.

50. Vo, X. V. (2017). Determinants of capital structure in emerging markets: Evidence from Vietnam. Research in International Business and Finance, 40(C), 105-113. DOI: https://doi.org/10.1016/j.ribaf.2016.12.001.

51. Wellalage, N. H. \& Locke, S. (2015). Impact of ownership structure on capital structure of New Zealand unlisted firms. Journal of Small Business and Enterprise Development, 22(1), 127-142. DOI: https://doi.org/10.1108/JSBED-09-2011-0004.

52. Yuliani, R. H. Umrie \& Diah, M. Y. (2014). Determinan Struktur Modal dan Pengaruhnya Terhadap Nilai Perusahaan pada Pasar yang Sedang Berkembang (Studi pada Sektor Real Estate and Property). Jurnal Manajemen Usahawan Indonesia, 43 (1), $27-52$.

53. Zhang, D. \& Liu, D. (2017). Determinants of The Capital Structure of Chinese Non-Listed Enterprises: Is TFP efficient. Economic Systems, 41(2), 179-202. DOI: https://doi.org/10.1016/j.ecosys.2016.12.003.

Ця робота ліцензована Creative Commons Attribution 4.0 International License 